\title{
Human colonic mononuclear cells: studies of cytotoxic function*
}

\author{
Z M FALCHUK, $\dagger$ ELIZABETH BARNHARD, AND IRMA MACHADO \\ From the Department of Medicine, Harvard Medical School and the Peter Bent Brigham Hospital, \\ A Division of the Brigham and Women's Hospital, Boston, Mass. USA
}

SUMMARY We isolated lymphocytes from the lamina propria of colon from 19 patients with inflammatory bowel disease, colon cancer, and certain benign conditions to determine: (1) if these lymphocytes could mediate mitogen-induced (MICC) and spontaneous cell-mediated cytotoxicity (SCMC), and (2) if there were any differences in cytotoxic effectiveness which could relate to the underlying disease. We found that lamina propria lymphocytes functioned well in MICC reactions with phytohaemagglutinin, but not concanavalin $A$ as the inducing mitogen (specific lysis $28 \pm 5 \%$ vs $5 \pm 3 \%$ ). Lamina propria lymphocytes did not mediate SCMC (specific lysis $0.3 \%$ ). Neither the presence of inflammation nor the underlying disease of the patient influenced the cytotoxic activity. Peripheral blood lymphocytes from normal subjects and patients performed well in MICC assay with both phytohaemagglutinin and concanvalin $\mathrm{A}$ as the inducing mitogen and were equally effective in SCMC reactions.

Lamina propria lymphocytes are located just beneath the surface epithelium of the intestine. Their strategic location within the mucosa, as well as their increase in diseases such as ulcerative colitis ${ }^{1}$ and gluten-sensitive enteropathy, ${ }^{2}$ has prompted the hypothesis that lamina propria lymphocytes may be important, not only to local immune responses, ${ }^{3}$ but possibly also to disease-related intestinal damage. Pursuit of this hypothesis has been hampered by lack of sufficient quantities of lamina propria lymphocytes for study. Development of techniques for the isolation of lamina propria lymphocytes has allowed initial characterisation of this lymphocyte population. ${ }^{4-8}$

Inherent to the idea that lamina propria lymphocytes may cause tissue damage in disease is the concept that lamina propria lymphocytes can mediate various mechanisms of cytotoxicity. Such mechanisms as antibody-dependent (ADCC), ${ }^{9}$ mitogen-induced (MICC), ${ }^{10}$ and spontaneous cellmediated cytotoxicity $(\mathrm{SCMC})^{11}$ are mediated by

\footnotetext{
*Presented in part at the Annual Meeting of the American Gastroenterological Association, New Orleans, Louisiana, May 1979 and published in Abstract form (Gastroenterology 76: 1129, 1979).

†Address for correspondence and reprint requests: $Z$ Myron Falchuk MD Peter Bent Brigham Hospital, A Division of Brigham and Women's Hospital, 75 Francis Street, Boston, Mass. 02115, (617) 732-5820.
}

Received for publication 29 October 1980 peripheral blood lymphocytes. These activities may also be present in lamina propria lymphocytes. However, it is not clear that lamina propria lymphocytes can mediate all these reactions-for example, ADCC. . 12 13-15 $^{2}$

The purpose of this study was to determine if isolated lamina propria lymphocyte populations of the colon mediate target cell killing by the mechanism of MICC, a T-cell function, ${ }^{10}$ and SCMC, a natural killer (NK) cell function. ${ }^{16}$ (The NK cell has an Fc receptor, but not surface immunoglobulin; there is controversy as to whether this cell may form rosettes with sheep red blood cells, ${ }^{17}$ as do $T$ cells).

\section{Methods}

\section{PATIENT GROUP}

Nineteen specimens from patients undergoing colectomy for a variety of diseases were obtained at the time of surgery. Eight patients had colon cancer, five had inflammatory bowel disease (three with Crohn's disease and two with ulcerative colitis) and six patients had various colonic diseases, including three with diverticulosis, one with an adenomatous polyp, one with an intestinal lipoma, and one with a redundant sigmoid colon. Squares of tissue measuring 5-10 cm (2-4 in) per side were cut for study from areas of the bowel which were normal ('uninvolved'). 
Eleven additional specimens were obtained from areas of the bowel which were grossly (and subsequently histologically) 'involved' with either cancer (six) or inflammatory bowel disease (three Crohn's disease, two ulcerative colitis). Peripheral blood lymphocytes were obtained from 10 healthy subjects, as well as from five of the 19 patients. All studies were approved by the Human Subjects Committee, Brigham and Women's Hospital, and informed consent was obtained from each participant.

PREPARATION OF EFFECTOR CELLS:

LAMINA PROPRIA LYMPHOCYTES

Lamina propria lymphocytes were isolated from colonic mucosa using the technique of Bull and Bookman. ${ }^{4}$ The procedure yielded mononuclear cells with $90 \%$ viability as estimated by trypan blue exclusion. The cell suspensions were maintained in RPMI-1640 medium (Grand Island Biological) containing $10 \%$ pooled $\mathrm{AB}, \mathrm{Rh}$-negative serum (American Red Cross Blood Services, Northeast Region, Boston, Mass.) and streptomycin, penicillin, amphotericin-B, and gentamicin. The preparation procedure does not alter the lymphocyte's ability to mediate ADCC, ${ }^{1314}{ }^{17} \mathrm{SCMC}^{1314}$ or MICC. ${ }^{13}{ }^{14} \mathrm{We}$ confirmed this in our laboratory by putting peripheral blood lymphocytes through the same isolation procedure and showing no significant effect of the procedure on the cytotoxicity values.

PERIPHERAL BLOOD LYMPHOCYTES

Peripheral blood lymphocytes were obtained by standard techniques involving centrifugation of blood over Ficoll-Hypaque ${ }^{\mathrm{R}}$ gradients. ${ }^{18}$

\section{TARGET CELLS}

Mouse mastocytoma tumour cell line, P815, was maintained by passage in Eagle's minimal essential medium (MEM, Grand Island Biological) with added fetal calf serum (FCS), penicillin, streptomycin, and used in the study of MICC. Human chronic leukaemia cell line, K562, was maintained in RPMI-1640 medium with $10 \%$ FCS and was used to test SCMC. In studies of cytotoxicity, both target cell lines were labelled ${ }^{19}$ with sodium chromate ${ }^{51}\left({ }^{51} \mathrm{Cr}\right)$ (New England Nuclear, Boston, Mass.). $1 \times 10^{4}$ target cells generally had 20000 counts per minute or more 'maximal releasable' counts (see below).

T CELL ENUMERATION

$T$ cells from lamina propria lymphocytes were enumerated by the sheep red blood cell (E-rosette) method. ${ }^{20}$ Sheep red blood cells were treated with 2-aminoethyisothiouronium bromide (AET) before being used. At least 200 cells per specimen were counted and results expressed as percentage rosettes out of total lymphocytes.

\section{CYTOTOXICITY TESTING}

MICC $^{10}$ was determined in V-bottom microtitre plates (Cooke Laboratories, Alexandria, Virginia) by adding mitogen, $1 \times 10^{4}{ }^{51} \mathrm{Cr}-\mathrm{P} 815$ target cells, and effector lymphocytes (lamina propria lymphocytes or peripheral blood lymphocytes) to appropriate wells. All assays were done in triplicate. Maximal releasable ${ }^{51} \mathrm{Cr}$ was determined by mixing labelled target cells with Triton X100. Spontaneous ${ }^{51} \mathrm{Cr}$ release was determined by incubation of target cells with no effector cells. The plates were harvested after 18 hours of incubation at $37^{\circ} \mathrm{C}$ by centrifuging at $900 \times g$ for 10 minutes at $4^{\circ} \mathrm{C}$. An aliquot of culture supernatant was counted in a liquid scintillation spectrometer.

The optimal concentrations of PHA and Con A for MICC assay were $10 \mu \mathrm{g} / \mathrm{ml}$ and $6.2 \mu \mathrm{g} / \mathrm{ml}$ (final concentration), respectively. In early experiments, various target:effector cell ratios were examined, ranging from 1:25 to 1:200. A plateau of activity was observed at a target-to-effector ratio of 1:50. This was used in the remainder of this study. Results were calculated according to the formula below and expressed as \% specific lysis. Spontaneous ${ }^{51} \mathrm{Cr}$ release from $\mathrm{P} 815$ cells averaged $28 \%$. Specific ${ }^{51} \mathrm{Cr}$ release from target cells incubated with PHA alone was $2-5 \%$. Specific ${ }^{51} \mathrm{Cr}$ release from target cells incubated with lamina propria lymphocytes alone was $1-2 \%$.

$\mathrm{SCMC}^{11}$ was determined using V-bottom microtitre plates. To the wells were added $1 \times 10^{4}{ }^{51} \mathrm{Cr}-$ K562 cells and effector lymphocytes (lamina propria lymphocytes or peripheral blood lymphocytes). Preliminary experiments showed that peripheral blood lymphocytes (PBL) had optimal killing at target: effector ratio of $1: 25$. Lamina propria lymphocytes (LPL) were used in ratios up to and including 1:100. The plates were incubated for 18 hours and harvested as above. Maximal ${ }^{51} \mathrm{Cr}$ release was determined as above. Spontaneous ${ }^{51} \mathrm{Cr}$ release was determined by incubation of K562 cells with media alone and averaged $10 \%$. Cytotoxicity was expressed as percentage specific target cell lysis obtained with the following formula:

$\%$ specific lysis $=$

experimental ${ }^{51} \mathrm{Cr}$ release-spontaneous ${ }^{51} \mathrm{Cr}$ release

maximal ${ }^{51} \mathrm{Cr}$ release - spontaneous ${ }^{51} \mathrm{Cr}$ release

$\times 100$

for MICC: experimental ${ }^{51} \mathrm{Cr}$ release $=$ target + mitogen + effector cells, spontaneous ${ }^{51} \mathrm{Cr}$ release $=$ target + mitogens, maximal ${ }^{51} \mathrm{Cr}$ release $=$ target + triton $\times 100$ (same for SCMC). 
Table $1 T$ cell percentages and cell-mediated cytotoxicity of lamina propria lymphocytes

\begin{tabular}{|c|c|c|c|c|c|}
\hline & \multicolumn{2}{|c|}{ Colon cancer } & \multicolumn{2}{|l|}{$I B D^{*}$} & \multirow{2}{*}{$\begin{array}{l}\text { Miscel- } \\
\text { laneous }\end{array}$} \\
\hline & Involved & Uninvolved & Involved & Uninvolved & \\
\hline$\% \mathrm{~T}$ cells & $\begin{array}{l}49 \% \pm 3 \\
\text { (3) }\end{array}$ & $\begin{array}{l}43 \% \pm 4 \\
\text { (3) }\end{array}$ & $\begin{array}{l}49 \% \pm 3 \\
\text { (5) }\end{array}$ & $\begin{array}{l}52 \% \pm 4 \\
(5)\end{array}$ & $\begin{array}{l}40 \% \pm 3 \\
\text { (2) }\end{array}$ \\
\hline $\begin{array}{l}\text { MICC } \\
\text { PHA } \\
\text { CON A } \\
\text { SCMC }\end{array}$ & $\begin{array}{c}30 \pm 13 \ddagger \\
<1 \\
<1\end{array}$ & $\begin{array}{r}23 \pm 9 \\
7 \pm 4 \\
<1\end{array}$ & $\begin{array}{r}25 \pm 7 \\
8 \pm 5 \\
<1\end{array}$ & $\begin{array}{r}15 \pm 4 \\
<1 \\
<1\end{array}$ & $\begin{aligned} & 25 \pm 8 \\
& 3 \pm 2 \\
&<1\end{aligned}$ \\
\hline & (6) & (8) & (5) & (5) & (6) \\
\hline
\end{tabular}

"IBD: inflammatory bowel disease.

†See text for diagnoses.

$\ddagger \%$ specific lysis (mean \pm standard error).

Parentheses indicate number of individuals tested.

Target-to-effector ratio for MICC was 1:50 and for SCMC ranged from $1: 25$ to $1: 100$

for SCMC: experimental ${ }^{51} \mathrm{Cr}$ release $=$ target + media + effector cells, spontaneous ${ }^{51} \mathrm{Cr}$ release $=$ target + media.

STATISTICAL METHODS

One-way analysis of variance and Student's $t$ test were determined with a Hewlett-Packard HP-67 computer.

\section{Results}

LAMINA PROPRIA LYMPHOCYTE PREPARATION Lamina propria lymphocyte preparations from involved and uninvolved colons yielded from $10 \times 10^{6}$ to $40 \times 10^{6}$ mononuclear cells per square $\mathrm{cm}$ of mucosa. The highest yields were from intestine involved with inflammation. Eighty to $95 \%$ of the cells were lymphocytes; macrophages and rare epithelial cells accounted for the remaining cells.

\section{T CELL PERCENTAGE}

Lamina propria lymphocytes forming rosettes with sheep red blood cells were determined in 18 specimens: three involved and three uninvolved with cancer, five involved and five uninvolved with inflammatory bowel disease, one with diverticulosis, and one with adenomatous polyp, respectively. Forty to $52 \%$ of the LPL formed E-rosettes. The percentage of E-rosettes was not significantly influenced by the underlying disease $(>0 \cdot 2)$ (Table 1$)$.

\section{CYTOTOXICITY-PERIPHERAL BLOOD}

LYMPHOCYTES

Peripheral blood lymphocytes from 10 normal individuals were examined for their capacity to mediate MICC and SCMC and compared with values obtained from five patients (three with colon carcinoma and one each with diverticulosis and polyposis) whose LPL were also studied. The PBL of the patients yielded results for MICC which,
Table 2 Cell-mediated cytotoxicity of peripheral blood lymphocytes

\begin{tabular}{llll}
\hline & \multicolumn{2}{l}{ Normals } & $\begin{array}{l}\text { Patients } \\
\text { (5) }\end{array}$ \\
\cline { 2 - 3 } & $\begin{array}{l}\text { Untreated } \\
(10)\end{array}$ & $\begin{array}{l}\text { Collagenase treated } \\
(5)\end{array}$ & \\
\hline MICC & $64 \pm 5$ & $62 \pm 4$ & $45 \pm 12$ \\
PHA & $44 \pm 8$ & $39 \pm 7$ & $26 \pm 8$ \\
CON A & $50 \pm 4$ & $46 \pm 5$ & $52 \pm 12$ \\
SCMC & & & \\
\hline
\end{tabular}

* \% specific lysis (mean \pm standard error).

Parentheses indicate number of individuals tested.

Target-to-effector cell ratio for MICC was 1:50 and for SCMC was $1: 25$.

although lower than values from normal subjects, were not significantly different $(P>0 \cdot 3)$. SCMC assays also resulted in values for normal subjects and patients which were not significantly different from each other $(P>0 \cdot 6)$. Thus, in this group, PBL from normal subjects and patients mediated both MICC and SCMC without any effect from the underlying disease (Table 2).

\section{CYTOTOXICITY-LAMINA PROPRIA \\ LYMPHOCYTES \\ Mitogen-induced cytotoxicity (MICC)}

LPL from all patient groups mediated MICC induced by PHA (Figure). Furthermore, no significant difference was detected between values of MICC of LPL from involved and uninvolved areas of the groups with cancer and inflammatory bowel disease $(P<0 \cdot 2)$ (Table 1). Therefore, neither the underlying disease among patient groups nor the presence or absence of disease involvement in individual specimens influenced the MICC cytotoxic activity of LPL induced by PHA.

MICC values for both PBL and LPL were strikingly lower when Con $A$ was the inducing mitogen $(\mathbf{P}<0.01)$ (Figure, Tables 1 and 2). Thus, Con Ainduced MICC was $31-42 \%$ less efficient than PHAinduced MICC when PBL were the effector cells (Table 2) and $84 \%$ less efficient when LPL were the effector cells (Figure). It appears from these data that the cells in LPL vs PBL which mediate Con Ainduced MICC are either diminished markedly, less effective, or are more readily suppressed by Con A. Treatment of PBL with the same reagents used to prepare the LPL had no influence on the ability of the PBL to mediate Con A or PHA-induced MICC (Table 2).

Spontaneous cell-mediated cytotoxicity (SCMC) In contrast with PBL, LPL were unable to mediate SCMC against K562 cells. The specific lysis for all specimens but one, regardless of disease diagnosis or activity, was less than $1 \%$. A single specimen from 


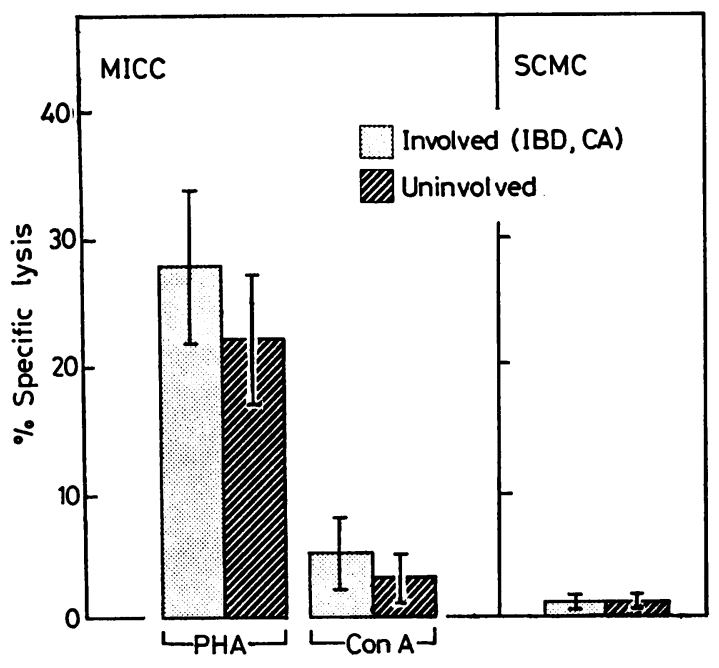

Figure Percentage specific lysis for P815 or K562 target cells by colon lamina propria lymphocytes in assays of mitogen-induced (MICC: P815) and spontaneous cell-mediated cytotoxicity (SCMC: K562). The bars show the mean \pm standard error of lamina propria lymphocytes from 11 specimens involved with inflammatory bowel disease or carcinoma (stippled), and 19 specimens either adjacent to inflamed or malignant areas or from colon specimens resected from patients with other diseases (hatched). Con $A$ is much less efficient than PHA in inducing MICC $(\mathrm{P}<0.01)$, and SCMC is not mediated by lamina propria lymphocytes at all.

a patient with cancer achieved a value of $12 \%$. In four specimens, effector-to-target ratios of up to 300:1 still did not produce SCMC activity. The PBL of the patients, in contrast with their LPL, had a mean value of SCMC of $52 \%$, not significantly different from normal controls (Tables 1 and 2). Incubation of PBL with the same reagents used to prepare the LPL did not affect the ability of the PBL to mediate SCMC (Table 2). Furthermore, incubation of LPL from three specimens of colon (one ulcerative colitis, two cancer) in medium for 40 hours to allow for possible regeneration of surface receptors did not result in these LPL gaining the ability to mediate SCMC (mean specific toxicity before incubation $1.2 \%$; after incubation, $1.8 \%$ ).

\section{Discussion}

We showed that LPL of human colon participate in the $T$ cell mediated mitogen-induced cytotoxic reaction (MICC). Con A is less effective than PHA in inducing MICC when PBL and LPL are the effector cells. Also, LPL appear to be functionally different from PBL, as, although they perform well in MICC when PHA is the mitogen, they perform more poorly than PBL when Con $\mathrm{A}$ is the inducing mitogen. There may be a relative paucity in the LPL population of the subset of $T$ cells capable of interacting with Con A to result in MICC activity with this mitogen. It has been proposed that adherent cells and monocytes could be needed for complete expression of MICC. ${ }^{21}$ It is suggested that the adherent cell population is more important for the expression of Con A-induced than PHA-induced cellular cytotoxicity. Differences in accessory cells in PBL $v s$ LPL could account, therefore, for the relative inability of the LPL to show effective MICC activity with Con A.

The finding in our study that LPL obtained from normal colon, colon uninvolved with cancer, and colon uninvolved with inflammation function equally in MICC without regard to the underlying disease leaves open the issue of relevance of the in vitro phenomenon of MICC to disease. We did not examine other target cells of potential interest, such as isolated colonic epithelial cells.

The cell which mediates SCMC is called the NK cell and may be identical with the $K$ cell, which mediates antibody-dependent cellular cytotoxicity reactions. ${ }^{22}$ We found the function of SCMC lacking in the LPL population of human colon using K562 cells as the target. This target is especially susceptible to SCMC killing ${ }^{11}$ and should show this function if it is present. It is noteworthy that the lack of SCMC activity occurs in 'normal' colon LPL as well as LPL from diseased colon. Inflammation and/or neoplasm per se, therefore, do not seem to attract NK cells or render the cells already present in the LPL functional in SCMC assays. Previous studies foreshadowed this finding: Clancy, ${ }^{12}$ Fiocchi et al., ${ }^{8}$ and Bookman and Bull ${ }^{15}$ showed that LPL from colon did not mediate ADCC, while Arnaud-Battandier et al.,17 showed that LPL from guinea-pig colon did not mediate ADCC or SCMC against the Chang cell line. It remains possible that lymphoid cells capable of mediating SCMC reactions are present in the LPL population, but their activity is suppressed by modulating or suppressor cells. Alternatively, the isolation procedure may remove a needed accessory cell. This is less likely, as PBL are not affected by the isolation procedure.

Chiba et al. ${ }^{13}$ and MacDermott et al., ${ }^{14}$ in contrast with others, ${ }^{8121517}$ showed that lamina propria lymphocytes are active in ADCC assays against chicken red blood cells (CRBC) ${ }^{1314}$ and Chang cells. ${ }^{13}$ However, the specific cytotoxic activity of lamina propria lymphocytes against Chang cells is quite low in Chiba's study (10-15\%) and nonexistent in MacDermott's study. ${ }^{14}$ Both results must, therefore, await confirmation before they can be 
accepted as definitively showing $\mathrm{K}$ cell activity by lamina propria lymphocytes. As the $K$ cell and the NK cell may, in fact, be the same cell, ${ }^{22}$ the lack of SCMC activity shown by us would go along with the lack of ADCC activity shown by others ${ }^{812} 1517$ using cell lines as targets. It remains unclear whether 'ADCC' against chicken red blood cells is different from ADCC against other targets.

Additional study of the biological characteristics of the lamina propria lymphocytes will be crucial to our understanding of their role, if any, in inflammatory diseases.

Dr Falchuk is a recipient of Research Career Development Award, AM 00210 and is supported in part by USPH Research Grant, AM 17684. Dr Machado is a recipient of a Travelling Fellowship from CONICIT, Caracas, Venezuela. The authors wish to thank Janis Bongiovanni for her patience, perseverance, and expert typing of this manuscript.

\section{References}

${ }^{1}$ Morson BC. Pathology of ulcerative colitis In: Kirsner $\mathrm{JB}$, Shorter RH, eds. Inflammatory bowel disease. Philadelphia: Lea and Febiger, 1975; 167-81.

${ }^{2}$ Falchuk ZM. Update on gluten-sensitive enteropathy. Am J Med 1979; 67: 1085-906.

${ }^{3}$ Falchuk ZM, Strober W. Gluten-sensitive enteropathy: intestinal synthesis of antigliadin antibody in vitro. Gut 1974; 15: 947-52.

'Bull DM, Bookmann MA. Isolation and functional characterization of human intestinal mucosal lymphoid cells. J Clin Invest 1977; 59: 966-74.

${ }^{5}$ Clancy RL. lsolation and kinetic charactistics of mucosal lymphocytes in Crohn's disease. Gastroenterology 1976; 70: 177-80.

${ }^{6}$ Rudzik O, Bienenstock J. Isolation and characteristics of gut mucosal lymphocytes. Lab Invest 1974; 30: 260-6.

${ }^{7}$ Goodacre R, Davidson R, Singal D, Bienenstock J. Morphologic and functional characteristics of human intestinal lymphoid cells isolated by a mechanical technique. Gastroenterology 1979; 76: 300-8.

${ }^{8}$ Fiocchi C, Battisto JR, Farmer RG. Gut mucosal lymphocytes in inflammatory bowel disease. Isolation and preliminary functional characterization. Digest Dis Sci 1979; 24: 705-17.
${ }^{9}$ Perlmann P, Perlmann H. Contactual lysis of antibodycoated chicken erythrocytes by purified lymphocytes. Cell Immunol 1970; 1: 300-15.

${ }^{10}$ Holm G, Perlmann P, Werner B. Phytohemagglutinininduced cytotoxic action of normal lymphoid cells on cells in tissue culture. Nature 1964; 203: 841-5.

"Pross HF, Baines MG. Spontaneous human lymphocyte-mediated cytotoxicity against tumor target cells. VI. A brief review. Cancer Immunol Immunother 1977; 3: 75-85.

${ }^{12}$ Clancy R, Pucci A. Absence of $\mathrm{K}$ cells in human gut mucosa. Gut 1978; 19: 273-6.

${ }^{13}$ Chiba M, Shorter RG, Thayer WR, Bartnik W, ReMine S. K-cell activity in lamina propria lymphocytes from the human colon. Digest Dis Sci 1979; 24: 817-22.

${ }^{14}$ MacDermott RP, Franklin GO, Jenkins KM, Kodner IJ, Nash GS, Weinrieb IJ. Human intestinal mononuclear cells. I. Investigation of antibody-dependent, lectin-induced and spontaneous cell-mediated cytotoxic capabilities. Gastroenterology 1980; 78: 47-56.

${ }^{15}$ Bookman MA, Bull DM. Characteristics of isolated intestinal mucosal lymphoid cells in inflammatory bowel disease. Gastroenterology 1979; 77: 503-10.

${ }^{16}$ West WH, Cannon GB, Kay HD, Bonnard GH, Herberman RB. Natural cytotoxic reactivity of human lymphocytes against a myeloid cell line: characterization of effector cells. J Immunol 1977; 118: 355-61.

${ }^{17}$ Arnaud-Battandier F, Bundy BM, O'Neill M, Bienenstock J, Nelson DL. Cytotoxic activities of gut mucosal lymphoid cells in guinea pigs. J Immunol 1978; 121: 1059-65.

${ }^{18}$ Boyum A. IV. Isolation of mononuclear cells and granulocytes from human blood. Scand J Clin Lab Invest 1968; 21 : suppl 97: 77-89.

${ }^{19}$ Nelson DL, Bundy BM, Blaese RM, Strober W. Cytotoxic effector function in organized gut-associated lymphoid tissue (GALT). Cell Immunol 1976; 22: 165-75.

${ }^{20} \mathrm{Kaplan} \mathrm{ME}$, Clark C. An improved rosetting assay for detection of human T-lymphocytes. J Immunol Meth 1974; 5: 131-5.

${ }^{21}$ Wislöff F, Fröland SS. Studies on the cytotoxic activity of human lymphoid cells activated by concanavalin A. Int Arch Allergy 1973; 45: 456-66.

${ }^{22}$ DeLandazuri MO, Silva A, Alvarez J, Herberman RB. Evidence that natural cytotoxicity and antibodydependent cellular cytotoxicity are mediated in humans by the same effector cell populations. J Immunol 1979; 123: $252-8$. 